Si

We have recently been contacted by a number o kractice nurses because they have been told that pea flow meters are single use devices and should not $b$ used for more than one patient. In general practic access to spirometry may be limited and health car professionals are reliant on peak flow meters fo sbjective assessment of lung function. There $i$ eoncern that patient care will suffer if they are unabl to confirm a diagnosis of asthma, monitor asthm बontrol or assess acute asthma severity with peak flo readings.

Fungal contamination of mini peak flow meters ha been reported but without recognition of any advers effects in specific patients ${ }^{1}$ To my knowledge ther are no other published reports relating to this issue.

In 1999, in response to concerns about cross infectio Awiaht Creutzfeldt-Jakob Disease and the risk o transmission, a Health Service Circula (1HSC1999/179) entitled "Controls assurance $i$ infection control: decontamination of medical devices was published. One action point stated "never re-us medical devices designated for single-use."

Rublications from the Medical Devices Agency (MD \$B2000(04) have re-iterated that single-use device must not be reused under any circumstances and tha the reuse of "single-use" devices has lega implications. In addition, a medical device has bee defined in the booklet, Devices in Practice ${ }^{2}$ Reak flo meters were listed as an example of a medical device

One possible solution to this problem would be $\mathrm{t}$ advise health professionals to always prescrib individual peak flow meters for patients. This ha dbvious cost implications. Alternatively we shoul follow the pragmatic approach of one PE manufacturer ${ }^{3}$ who has recently re-published hygien Pnstructions for PEF meters where they are used in G or hospital clinics

Perhaps there has been an over-zealous interpretatio कf the theoretical risk of infection through the re-use o keak flow meters, in the absence of an established lin between multiple device use and infection. Ther is a need for research into the relationship betwee device contamination and disease before evidenc based guidelines can be established.

Frisha Welle

Head of Quality Assuranc

National Respiratory Training Centre (NRTC Narwic

\section{Reference}

1. Ayres JG et $a$ kFungal contamination of mini pea flow meters. Respiratory Medicin 1989; 8 :503-504 R. Medical Devices Agency. Devices in Practice. 200 乙ISBN 1841823597

B. Clement Clarke. Decontamination of Clemen

Clarke Respiratory Products. Issue 1. 200

\title{
Simply Evidence-Based Medicine: A book revie
}

\author{
Aziz Sheik
}

$\mathrm{S}$ imply Evidence-Based Medicine, the lates gddition to the National Respiratory Trainin Centre's popular 'Simply...Pocket Books' series aims to 'describe how research evidenc may be integrated into everyday clinica practice to improve patient care' Divided into four colour-coded sections ,Introducing evidence-based medicine' 'Finding published evidence' 'Understanding published papers' an iCollecting and using evidence $\mathrm{i}$ practice', it serves as a very readabl antroduction to Evidence-Base Medicine, highlighting its potential to enhance the quality of routin clinical care.

E was pleasantly surprised by th

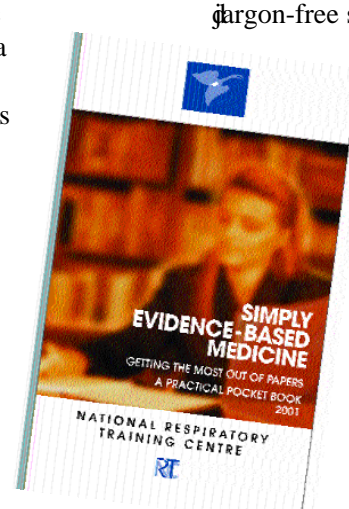
flowcharts, graphs and tables, ensure that the mos jmportant messages are conveyed in an easil accessible manner. This book serves as an excellen ghargon-free synopsis of Evidence-Based Medicine an dill, I believe, appeal to a broa mange of health professionals wh bave hitherto found it difficult $t$ engage effectively with the evidence based approach to delivering clinica care. I recommend it wholeheartedly!

All enquiries regarding the boo should be directed to the Nationa Respiratory Training Centr

Telephone: +44 (0)1926 493313 Email: v.pearson@nrtc.org.uk http://www.nrtc.org.uk

\section{Aziz Sheik}

Greneral Practioner an

SH R\&D Nationa

grimary Care Trainin Fiello

Dept. Primary Care an Eeneral Practic

Eaculty of Medicin Imperial College Schoo of Science, Technolog and medicin Charing Cross Campu 8t Dunstan's Roa hondo

kziz.sheikh@ic.ac.u

Prim Care Respir 2002 11(2) 9 